\title{
The Role of Egoistic Motives for Malaysian College Students' Involvement in Volunteering Activities
}

\author{
A. Nazilah ${ }^{1}$, I. Rozmi ${ }^{2}$ \& I. Fauziah ${ }^{2}$ \\ ${ }^{1}$ Psychology and Counseling Department, School of Social and Economic Development, University Malaysia \\ Terengganu, Malaysia \\ ${ }^{2}$ School of Psychology and Human Development, Faculty of Social Sciences and Humanities, the National \\ University of Malaysia, Malaysia \\ Correspondence: A. Nazilah, Department of Psychology and Counseling, School of Social and Economic \\ Development, University Malaysia Terengganu, 21030 Kuala Terengganu, Terengganu, Malaysia. Tel: \\ 60-96-68-3137. Email: nazilah@umt.edu.my
}

Received: July 2, 2013 Accepted: July 30, 2014 Online Published: September 29, 2014

doi:10.5539/ass.v10n19p173 URL: http://dx.doi.org/10.5539/ass.v10n19p173

\begin{abstract}
Egoistic motives play an important role for the involvement of college students in volunteering activities. This study extends the prior research to the Malaysian context and aims to emphasize on descriptive analysis of egoistic motives. A quantitative cross sectional survey research method was used to collect data. A self-administered questionnaire comprised of a demographic and an adaptation of Volunteer Function Inventory (VFI) was administered to samples from four public universities in Peninsular Malaysia. They were proportionately and randomly selected in the study. Data were analyzed using descriptive analysis. In a sample of 310, the results of the study revealed that egoistic motives in terms of career needs, self-protection and social needs were from high to very high level. The results also showed that the need to reduce the feeling of loneliness had recorded the highest mean of items. Besides, the results found that majority of the respondents acknowledged that egoistic motives were important for their involvement in volunteering activities. Meanwhile, 96 per cent of them acknowledged that the most important reason for their involvement in volunteering activities was to protect them from loneliness. The implications for theory and volunteers' managerial practices are discussed and put forward.
\end{abstract}

Keywords: college students, egoistic motives, volunteers, volunteerism

\section{Introduction}

Volunteering plays a vital role for the development and wellbeing of a community. In fact, the impact of volunteering is not only concern with productivity and responsibility of a citizen but also the wellbeing of others. Hence, its spirit and application will lead to stability and peace of a nation. The government should give special attention to college students' involvement in volunteering activities because they are a very significant population. They are future leaders who will continue the development and wellbeing of a society and nation (Azizan, 2004). They are highly educated people and the role model to community. They also have strong power of peer influences because most of them are young people (Newman \& Newman, 2006) and intellectuals see them as a potential group to influence their peers positively. In addition, college students also responsible to meet part of the goals of a university that is to serve community.

Recently, Malaysian government had launched 1M4U and had provided special grants for the youth including the college students to organize volunteering activities (Ministry of Youth \& Sports Malaysia, 2013). The government also embedded volunteerism element in Malaysian national education policies (Ministry of Education Malaysia, 2013). These are as the facts that Malaysian government realizes the importance of college students' involvement in volunteering activities. However, researchers are not yet investigate why Malaysian college students involve in volunteering activities scientifically.

The Functional theory explains that a person's attitude or behavior may be serve different psychological needs (Houle, Saragin \& Kaplan, 2005; Katz, 1960). Past literatures have found the role of egoistic motives for the involvement of adults (Clary \& Snyder, 1991, 1999; Clary, Snyder, Ridge, Copeland, Stukas, \& Haugen, 1998; 
Snyder, Clary \& Stukas, 2000) and students in volunteering activities (Abrami \& Perry, 1976; Batson \& Coke, 1981; Devlin \& Trudeau, 1996; Fitch 1987; Serow, 1991; Smith, 1981). However, most of those studies have done in overseas. This study extends the prior research to the Malaysian context and aims to analyze the egoistic motives in depth. The research gap and the lack of research on volunteering motivation among Malaysian college students' volunteers have attracted the researchers to conduct this study. In addition, people cannot apply the results of volunteering motivation studies among adult volunteers that get much more attention in this area to another generation automatically as volunteering motivation changes over time (Kirkpatrick Johnson, Beebe, Mortimer, \& Snyder, 1998; Omoto, Snyder, \& Martino, 2000). Besides, volunteering studies are highly recommended for the development of volunteerism in Malaysia (Saifuddin, 2001).

Encyclopedia of School Psychology (2007) explains that motivation is a force behind the behavior and motivation is to explain why someone does something. Encyclopedia of Social Psychology (2007) defines the behavior of volunteerism as a voluntary service to others, from time to time and without any compensation. Volunteering motivation in this study refers to the egoistic motives (career, self-protection and social). Egoistic motives refer to the behaviors that aim to get psychosocially benefit from the involvement in volunteering activities. Batson (1991) pointed out that if the main purpose of volunteers is to benefit them, then he classified the behavior as egoistic, although the behavior can benefit to others. Career motives aim to gain career experiences through volunteering activities. Self-protection motives refer to the need of negative state relief. Social motives refer to volunteering behaviors to strengthen social relationships.

Motivation factors play an important role for the involvement of volunteers in volunteering activities. Researchers found that volunteering motives led to long-term volunteering behaviors (Clary, Snyder, Ridge, Miene, \& Haugen, 1994; Omoto \& Snyder 1995; Stukas, Synder, \& Clary, 1999). Clary et al. (1998) and Jimenez, Fuertes, Abad (2010) found that volunteers tended to remain as a volunteer as long as the benefit they gained from volunteering activities compatible with their motivation. In another study, researchers found that egoistic motives were important in determining the survival of students' involvement in volunteering activities (Batson \& Coke 1981; Smith 1981). Winniford, Carpenter \& Girden (1995) also found the benefits derived from students' involvement in volunteering activities were important. Studies on commitment of student volunteers in sport event (Sharififar, Jamalian, Nikbakhsh, 2011) and welfare (Siti Nazilah, Rozmi, Fauziah, 2012a \& 2012b) also found the importance of egoistic motives. These findings support the recommendations of Phillips (1982) who stress on the importance of volunteerism in the context of Social Exchange Theory that looking at the existence of resource conversion factors from altruistic aspects (serving the others) and egoistic aspects (gaining benefits). Both of these factors form the basis of all social interaction. Fitch (1987) found that the influences of egoistic factor among students' volunteers were higher than altruistic factors. Result of the study explains that self-interest factor is more important for students' volunteers. On the other hand, Omoto, Synder and Hackett (2010) found that altruistic motivation predicted the involvement of AIDS volunteers better than egoistic motivation. However, samples of the study were adult volunteers. Nelson, Hooker, DeHart, Edwards and Lanning (2004) found that young volunteers were more highly motivated by self-improvement needs.

Studies also showed that there were various reasons that motivated volunteering behavior (Clary \& Snyder 1991, 1999; 1998; Kim, 2010; Snyder \& Omoto, 1992a, 1992b; Snyder et al., 2000). The egoistic motives of volunteering included obtaining career experiences, exploring career options, reducing guilty feeling, relieving problems, getting social acceptance, strengthening social relationships and so forth. The various driving factors also explained why certain individuals continued to be a volunteer for a long period of time (Clary et al., 1998).

Functional Theory explains that people may have different motives for a particular attitude or behavior and people may have multiple motives for a single behavior (Houle et al., 2005; Katz, 1960). One of the psychological motives identified by Katz (1960) is a utilitarian function. Utility function refers to attitudes or behaviors that based on rewards. Researchers also used this theory to understand the basic motivation in volunteerism (Snyder, 1993). Another theory that related to this study is Maslow's Hierarchy of Needs. The theory believed that human needs played a major role in motivating behavior. There are five different levels of Maslow's Hierarchy of Needs. First, physiological needs such as the need of water, air, food and sleep. Second, safety and security needs such as the need of pleasant feeling, steady career and safe neighborhoods. Third, social needs such as needs for belongings, love and affection. Fourth, esteem needs such as needs for self-esteem, social recognition and accomplishment. Fifth, self-actualization needs such as personal growth and fulfilling of an individual potential (McGuire, 2012).

This study aims to measure egoistic motives for volunteering among Malaysian college students' volunteers. Specifically, there are three objectives of the study. First, to describe the demographics of Malaysian college students' volunteers. Second, to measure egoistic motives and lastly to identify the priority of egoistic motives. 


\section{Method}

This study used a quantitative cross-sectional survey method. Participants were student college volunteers from four public universities in Peninsular Malaysia. The researchers chose the participants by stratified random sampling. The person in charge was approached after permission and consent was obtained from vice chancellors of universities. The researchers administered the questionnaires to participants in four venues at different time. Three hundred and fifty questionnaires were distributed to participants. The researchers asked the participants to complete the questionnaires anonymously and voluntarily and return it to the researchers immediately. There were 40 questionnaires were excluded from data analysis due to incomplete responses and outliers.

The mean age of the respondents was 21.86 years with an average of 13.55 months of involvement in the current volunteer club. Out of the 310 respondents, more than half (68.4\%) were females. The average time contributed to the club and volunteering activities was 7.35 hours per month. The mean year of their study was 2.24 .

The data of this study were obtained through a set of self-administered questionnaire comprised of a demographic and volunteer motivation scale. Motivation scale was an adaptation of Volunteer Function Inventory (Clary et al., 1998). It measured motivation using 15 items that were rated on a 7-point likert type scale ranging " not at all important / accurate (1), not important / accurate (2), slightly not important / accurate (3), neither not important / accurate nor important / accurate (4), slightly important / accurate (5), important / accurate (6) and strongly important / accurate (7). Aspects of egoistic motives addressed were career, self-protection and social motives. Cronbach's alpha of VFI constructs showed high reliability for career (.84), self-protection (.86) and social (.81). As the original scale was in English, professionals translated this measure into Malay using back-to-back translation method. There were two steps involved. First, the English version of the measure was translated into Malay. Second, the Malay version of the measure was translated back into English.

\section{Results and Discussion}

The result found that the majority of respondents $(91.9 \%)$ agreed that they involved in volunteering activities in order to establish relationships with new contacts that could help in their career (item 2). This item had recorded the highest mean for the career motives (5.96).The results also showed that majority (91.6\%) of respondents admitted that they volunteered to enhance the value of their resume (item 5). Most of the respondents (92.3\%) also acknowledged that volunteer services allowed them to explore various career options (item 3). While 89.7 per cent, admitted that volunteering could help them to succeed in their chosen careers (item 4).

The study also found that majority $(96 \%)$ of respondents acknowledged that their involvement as volunteers because volunteering works could reduce the feeling of loneliness (item 7). This statement had recorded the highest mean 6.05 compared to all items of egoistic motives. Besides, majority (91\%) admitted that they volunteered to reduce feelings of guilt (item 8). Most of the respondents (89\%) also recognized that volunteering works could help them to forget their problems (item 6). While 88 per cent, admitted that volunteering could help them in dealing with their personal problems (item 10).

The study also found that majority of respondents (90\%) acknowledged that people close to them put a high value on community service (item 14). The mean of this statement had recorded the highest value of 5.85. The study also showed that 88.4 per cent of respondents acknowledged that people they knew were equally interested in community service activities (item 13). The respondents (80\%) acknowledged that their friends also volunteered (item 11). While 77.8 per cent of respondents acknowledged that people they closed to wanted them to volunteer (item 12). Please refer to Table 1 for details.

The findings showed that egoistic motives (career, self-protection and social) were salient for the involvement of Malaysian college students in volunteering activities. The findings also showed that the need to reduce loneliness was the most important drive compared to the other egoistic motives. The findings explained that the most importance reason why Malaysian college students involved in volunteering activities was to release the negative state of loneliness. It supported the findings of a study done by Serow (1991). Most probably, they feel lonely as being away from their family even though their friends are around. Probably, they are not really well adapted with the campus life since the averages of them are still in early years of study. The study also showed that factor analysis approach that emphasized on broader theme could not identify motives that are more specific. Hence, researchers tend to overlook other potential and more specific motives. In this study for example, self-protection motives encompass many types of negative state relief. Meanwhile a particular negative state relief sometimes depends on a particular volunteering behavior that is suit to an individual. 
Table 1. Descriptive analysis of egoistic motives (career, self-protection and social) among Malaysian college students' volunteers

\begin{tabular}{|c|c|c|c|c|c|c|c|c|c|}
\hline \multirow[t]{2}{*}{ No. } & \multirow[t]{2}{*}{ Item } & $\begin{array}{l}\text { not at all } \\
\text { important } \\
\text { (1) }\end{array}$ & 4 & (3) & (4) & (5) & (6) & $\begin{array}{l}\text { strongly } \\
\text { important } \\
\text { (7) }\end{array}$ & \multirow[t]{2}{*}{ Mean } \\
\hline & & $f(\%)$ & $f(\%)$ & $f(\%)$ & $f(\%)$ & $f(\%)$ & $f(\%)$ & $f(\%)$ & \\
\hline \multicolumn{10}{|c|}{ Career Motives } \\
\hline $1-$ & $\begin{array}{l}\text { Volunteering can help me to get my } \\
\text { foot in the door at a place where I } \\
\text { would like to work }\end{array}$ & 1.9 & 1.0 & 2.9 & 11.3 & 25.2 & 31.3 & 26.5 & 5.56 \\
\hline $2-$ & $\begin{array}{l}1 \text { can make new contacts that might } \\
\text { help my business or career }\end{array}$ & 1.0 & 0.3 & 0.6 & 6.1 & 19.7 & 36.1 & 36.1 & 5.96 \\
\hline $3-$ & $\begin{array}{l}\text { Volunteering allows me to explore } \\
\text { different career options }\end{array}$ & 0.3 & 0.3 & 0.6 & 6.5 & 22.6 & 38.4 & 31.3 & 5.91 \\
\hline 4- & $\begin{array}{l}\text { Volunteering will help me succeed } \\
\text { in my chosen profession }\end{array}$ & 0.3 & 0.3 & 1.9 & 7.7 & 23.9 & 43.5 & 22.3 & 5.74 \\
\hline $5-$ & $\begin{array}{l}\text { Volunteering experience will look } \\
\text { good on my resume }\end{array}$ & 0.6 & 0.6 & 1.3 & 5.8 & 18.7 & 38.1 & 34.8 & 5.95 \\
\hline \multicolumn{10}{|c|}{ Self-protection Motives } \\
\hline $6-$ & $\begin{array}{l}\text { No matter how bad I have been } \\
\text { feeling, volunteering helps me to } \\
\text { forget about it }\end{array}$ & 1.3 & 1.0 & 1.6 & 7.1 & 24.5 & 34.5 & 30.0 & 5.76 \\
\hline $7-$ & By volunteering I feel less lonely & 0 & 0.6 & 0.6 & 2.6 & 23.5 & 34.8 & 37.7 & 6.05 \\
\hline $8-$ & $\begin{array}{l}\text { Doing volunteer work relieves me } \\
\text { of some of the guilt over being } \\
\text { more fortunate than others }\end{array}$ & 0.6 & 1.0 & 1.3 & 6.1 & 24.2 & 38.1 & 28.7 & 5.81 \\
\hline 9- & $\begin{array}{l}\text { Volunteering helps me work } \\
\text { through my own personal problems }\end{array}$ & 1.3 & 0.6 & 3.5 & 6.5 & 20.3 & 41.6 & 26.1 & 5.73 \\
\hline $10-$ & $\begin{array}{l}\text { Volunteering is a good escape from } \\
\text { my own troubles }\end{array}$ & 1.6 & 2.9 & 3.2 & 10.3 & 22.9 & 35.2 & 23.9 & $5: 51$ \\
\hline \multicolumn{10}{|c|}{ Social Motives } \\
\hline $11-$ & My friends volunteer & 0.3 & 1.6 & 2.9 & 15.2 & 18.7 & 35.2 & 26.1 & 5.60 \\
\hline $12-$ & $\begin{array}{l}\text { People I am close to want me to } \\
\text { volunteer }\end{array}$ & 1.9 & 1.9 & 3.9 & 14.5 & 22.3 & 28.7 & 26.8 & 5.46 \\
\hline $13-$ & $\begin{array}{l}\text { People I know share an interest in } \\
\text { community service }\end{array}$ & 1.3 & 0.6 & 1.6 & 8.1 & 21.6 & 36.8 & 30.0 & 5.78 \\
\hline $14-$ & $\begin{array}{l}\text { Others with whom I am close place } \\
\text { a high value on community service }\end{array}$ & 1.0 & 1.3 & 2.3 & 5.5 & 18.4 & 40.3 & 31.3 & 5.85 \\
\hline 15- & $\begin{array}{l}\text { Volunteering is an important } \\
\text { activity to the people I know best }\end{array}$ & 2.6 & 1.3 & 2.3 & 15.8 & 27.7 & 33.9 & 16.5 & $5: 32$ \\
\hline
\end{tabular}

The findings also confirmed that highly motivated college students tended to involve in volunteering activities. College students also interested to participate in volunteering activities because the activities were appropriate to their egoistic motives. The findings supported the previous studies of egoistic volunteering motives (Abrami \& Perry, 1976; Devlin \& Trudeau, 1996; Fitch, 1987; Serow, 1991). The results of this study also supported the Functional Theory (1960) asserting that specific reasons drive human behaviors. The findings also supported the Theory of Maslow's Hierarchy Needs of the importance of psychological motives in determining human behavior. Results of this study are consistent with the previous studies among adults' volunteers in voluntary organizations (Clary \& Snyder, 1991, 1999; Clary et al., 1998; Snyder et al., 2000). Thus, these findings confirmed that college students also share the same values with other groups of ages. However, they differ in terms of their dominant needs of volunteers.

Despite of the contributions of this study, there are several potential limitations and compelling needs for further research. First, there is a limitation of external validity since the researchers collected the data of this study from volunteers who are members of a volunteer club. Thus, the generalization of the findings is limited. Therefore, it is necessary to expand the data sources to include various types of Malaysian college students' volunteers. It 
may be worthwhile to extend this study to include college students' volunteers across other countries with different cultures. Second, this study analyzed only three types of egoistic motives. Therefore, further research should confirm the findings with inclusion of other egoistic volunteering motives. Third, this research only addressed to descriptive analysis. Hence, the study is not sufficient to confirm relationships between variables. Thus, the researchers recommend conducting empirical research that using advanced research methods and statistical analyses to examine the relationship between egoistic motives and involvement in volunteering activities.

\section{Conclusion}

This study has theoretical and practical importance. The findings supported the behavior theories that believed on the role of needs and motives in human behavior. This study also enriched the knowledge of volunteering field especially with the application of different context and approach. The results also provide valuable information for student affairs, development division of the higher public educations of Malaysia and volunteer's professionals to understand and recognize the role of egoistic motives in the involvement of Malaysian college students in volunteering activities. Therefore, they should facilitate, provide and encourage egoistic motives among college students' volunteers to improve their involvement in volunteering activities. Chancellors of universities as well as related officers and advisors should pay attention to establishing systems and programs that encourage egoistic motives. The findings of this research can create an avenue for future research that will lead to improvements in this critical area of college students' volunteers practice.

\section{Acknowledgments}

The researchers have been supported generously by respected Ministry of Education Malaysia, Student Affairs and Development Division of Public Higher Education Malaysia, the School of Social and Economic Development, University Malaysia Terengganu, Malaysia and the Faculty of Social Sciences and Humanities, The National University of Malaysia. The researchers would like to express sincere appreciation for all the support provided.

\section{References}

Abrami, P. C., \& Perry, R. P. (1976). Recruitment of college volunteers for community service organizations using the lecture method. Journal of Community Psychology, 4, 369-377.

Azizan, B. (2004). Generasi muda menangani cabaran (pp. 63-71). Alor Setar: Yayasan Dr. Rodzi.

Batson, C. D. (1991). The altruism questions: Toward a social-psychological answer (pp. 1-14). Hillsdale, NJ: Erlbaum.

Batson, C. D., \& Coke, J. S. (1981). Empathy: A source of altruistic motivation for helping? In J. P. Rushton, \& R. Sorentino (Eds.), Altruism and Helping Behavior (pp. 167-186). Hillsdale, NJ: Erlbaum.

Clary, E. G., \& Snyder, M. (1991). A functional analysis of altruism and prosocial behavior: The case of volunteerism. Review of Personality and Social Psychology, 12, 119-148.

Clary, E. G., \& Snyder, M. (1999). Motivations to volunteer: Theoretical and practical considerations. Current Directions in Psychological Science, 8, 156-159.

Clary, E. G., Snyder, M., Ridge, R. D., Copeland, J., Stukas, A. A., \& Haugen, J. (1998). Understanding and assessing the motivations of volunteers: A Functional Approach. Journal of Personality and Social Psychology, 74, 1516-1530.

Clary, E. G., Snyder, M., Ridge, R. D., Miene, P. K., \& Haugen, J. A. (1994). Matching messages to motives in persuasion: A Functional Approach to promoting volunteerism. Journal of Applied Social Psychology, 24, 1129-1149.

Devlin, A. S., \& Trudeau, K. J. (1996). College students and community service: Who, with whom and why? Journal of Applied Social Psychology, 26, 1867-1888.

Encyclopedia of School Psychology. (2007a). (pp. 331-335). SAGE Publications, Inc. http://dx.doi.org/10.4135/ 9781412952491

Encyclopedia of Social Psychology. (2007b). (p. 1016). SAGE Publications, Inc. http://dx.doi.org/10.4135/ 9781412956253

Fitch, R. T. (1987). Characteristics and motivations of college students volunteering for community service. Journal of College Student Personnel, 28, 424-431. 
Houle, B. J., Saragin, B. J., \& Kaplan, M. F. (2005). A Functional Approach to volunteerism: Do volunteers motives predict task performance? Basic and Applied Social Psychology, 27, 337-344.

Jimenez, M. L. V., Fuertes, F. C., \& Abad, M. J. S. (2010). Differences and similarities among volunteers who drop out during the first year and volunteers who continue after eight years. Spanish Journal of Psychology, 3, 343-352. http://dx.doi.org/10.1017/S1138741600003905

Katz, D. (1960). The Functional Approach to the study of attitudes. Public Opinion Quarterly, 24, 163-204.

Kim, M., Zhang, J. J., \& Connaughton, D. P. (2010). Comparison of volunteer motivations in different youth sport organizations. European Sport Management Quarterly, 10, 343-365. http://www.tandfonline.com/doi/ abs/10.1080/1618474

Kirkpatrick Johnson, M., Beebe, T., Mortimer, J. T., \& Snyder, M. (1998). Volunteerism in adolescence: A process perspectives. Journal of Research on Adolescence, 8, 309-332.

McGuire, K. J. (2012). Maslow's hierarchy of needs (pp. 5-6). GRIN Verlag.

Ministry of Education Malaysia. (2013). Malaysia education policy. Retrieved from http://www.moe.gov.my/ userfiles/file/BUKU\%20DASAR.pdf

Ministry of Youth \& Sports Malaysia. (2013). RM 100 juta untuk mantapkan aktiviti kesukarelawan. Retrieved from Available from http://www.kbs.gov.my/1m4u_v2/index.php?

Nelson, H. W., Hooker, K., DeHart, K. N., Edwards, J. A., \& Lanning, K. (2004). Factors important to success in the volunteer long-term care ombudsman role. The Gerontologist, 44, 116-120.

Newman, B. M., \& Newman, P. R. (2006). Development through life: A psychosocial approach (pp. 348-382). Belmont, CA: Thomson Wadsworth.

Omoto, A. M., \& Snyder, M. (1995). Sustained helping without obligation: Motivation, longevity of service and perceived attitude change among AIDS volunteers. Journal of Personality and Social Psychology, 68, 671-686.

Omoto, A. M., Synder, M., \& Hackett, J. D. (2010). Personality and motivational antecedents of activism and civic engagement. Journal of Personality, 78, 1703-734.

Omoto, A. M., Snyder, M., \& Martino, S. C. (2000). Volunteerism and the life course: Investigating age-related agendas for action. Basic and Applied Social Psychology, 22, 181-197.

Phillips, M. (1982). Motivation and expectation in successful volunteerism. Journal of Voluntary Action Research, 11, 118-125.

Saifuddin, A. (2001). Gerakan kesukarelaan menjana perubahan bermakna (pp. 39-47). Kuala Lumpur: Majlis Belia Malaysia, Yayasan Salam Malaysia dan Akademi Belia.

Serow, R. C. (1991). Students and volunteerism: Looking into the motives of community service participants. American Educational Research Journal, 28, 543-556.

Sharififar F., Jamalian Z., Nikbakhsh R., \& Ramezani Z. N. (2011). Influence of social factors and motives on commitment of sport events volunteers. Technics Technologies Education Management, 6, 184-190. Retrieved from http://medwellonline.net/ref.php?doi=ibm.2012.512.516

Siti Nazilah, M. A., Fauziah, I., \& Rozmi, I. (2012a). Relationship between motivation and organizational commitment among college student volunteers. International Business Management, 6(4), 512-516.

Siti Nazilah, M. A., Fauziah, I., \& Rozmi, I. (2012b). Relationship between satisfaction and organizational commitment among undergraduate volunteers. Social Sciences, 7(3), 378-382.

Smith, D. H. (1981). Altruism, volunteers and volunteerism. Journal of Voluntary Action Research, 10, 21-38.

Snyder, M. (1993). Basic research and practical problems: The promise of a functional personality and social psychology. Personality and Social Psychology Bulletin, 19, 251-264.

Snyder, M., \& Omoto, A. M. (1992a). Volunteerism and society's response to the HIV epidemic. Current Directions in Psychological Science, 1, 13-116.

Snyder, M., \& Omoto, A. M. (1992b). Who Helps and Why? The psychology of AIDS volunteerism. In. S. S. S. Oskamp (Ed.), Helping and Being Helped: Naturalistic Studies (pp. 213-239). Newbury Park, CA: Sage.

Snyder, M., Clary, E. G., \& Stukas, A. A. (2000). The Functional Approach to volunteerism. In G. R. Maio, \& J. M. Olson (Eds.), Why We Evaluate: Functions of Attitudes (pp. 365-393). Mahwah, NJ: Lawrence Erlbaum 
Associates, Inc.

Stukas, A. A., Synder, M., \& Clary, E. G. (1999). The effects of mandatory volunteerism on intentions to volunteer. Psychological Science, 10(1), 59-64.

Winniford, Carpenter, \& Girden. (1995). An analysis of the traits and motivations of college students involved in service organizations. Journal of College Student Development, 36, 27-38.

\section{Copyrights}

Copyright for this article is retained by the author(s), with first publication rights granted to the journal.

This is an open-access article distributed under the terms and conditions of the Creative Commons Attribution license (http://creativecommons.org/licenses/by/3.0/). 